\title{
AUTORIDAD MORAL DE UN CRITICO DE ARTE
}

\section{Por Elisa García Barragán}

Justino Fernández, a las muchas facetas de su labor como crítico e historiador del arte, une la de asesor artístico de gran calidad. Tarea ésta de no menor mérito y sí de muchísima importancia para la conservación de nuestro patrimonio cultural. Sus múltiples conocimientos, su inteligencia, fina sensibilidad, honradez intelectual y también - por qué no decirlosu imaginación, lo llevaron a ser la persona idónea para aconsejar en todo aquello que estuviera relacionado con el incremento, conservación, restauración y respeto a nuestro acervo histórico y artístico.

Las asesorías que constantemente se le pidieton fueron de temas muy diversos: sobre autenticidad de pinturas; importancia y valor de exposiciones artísticas que se deseaba enviar al extranjero; establecimiento, construcción, dotación y arreglo de museos; mejoras materiales tanto de la ciudad de México como de la provincia $y$, por supuesto, restauración y salvaguarda de los monumentos. A todas estas consultas Justino Fernández respondió con juicios siempre certeros y honrados. Utilizó en muchos casos para la defensa de la obra artística, la prensa periódica y escritos enviados directamente a las autoridades correspondientes, en los que insistía en lo importante que es para un país la conservación de su legado de arte e historia.

Creo pertinente antes de mencionar algunos de los muchos consejos que le fueron pedidos a Justino Fernández, el hacer referencia a su juicio con respecto a la actitud que se debe guardar frente a los monumentos artísticos para decidir su conservación o desaparición. Ese parecer expuesto por él en el artículo "El ciprés de la Catedral", 1 es de gran valor y ejemplo de lo concienzudo que fue siempre para emitir sus dictámenes.

En 1956, Justino Fernández, manifestó su opinión acerca de los diversos criterios que hay que tomar en cuenta para la eliminación de una obra de arte y trae a colación el ciprés de Lorenzo de la Hidalga, que estaba en la Catedral Metropolitana:

El criterio de destruir las señales que van dejando los tiempos, los gustos, las ideas, los hombres, no siempre es aceptable, aunque sea por razones de mejoramientos estéticos. Tampoco es todo $\tan$ sagrado $e$ intocable que

1 Fernández, Justino. "El ciprés de la Catedral Metropolitana." Historia Mexicana. México, julio-septiembre, 1956, p. 92. 
unos hombres tengan que cargar con los errores de otros. Se impone un criterio estético, uno funcional, o bien uno histórico. Es cuestión de decidirse por alguno según los casos. El ciprés de De la Hidalga desapareció sin pena ni gloria; hoy día casi nos congratulamos de ello, y sería de desearse que no se levantara otro más.

Ahora bien, ¿cuáles son las cualidades y conocimientos que un crítico de arte debe aplicar para proceder atinadamente y con justicia frente a un fallo difícil? A esos requisitos hizo mención varias veces Justino Fernández $-\mathrm{y}$ a ellos se atuvo- a través de las muchas entrevistas que se le hicieron, en las que declaró el método a seguir:

El estudio de la obra, su análisis: formal y significativo su comparación con otras en el pasado y en su tiempo, su lugar en la obra entera de un artista y de éste en el periodo histórico a que pertenece.

Creo que hay que agotar las posibilidades razonables de conocimiento, pero eso no es todo, lo demás proviene de la intuición, de la sensibilidad, de la imaginación. Para mí ni la crítica que solo es erudición es buena, ni tampoco la "impresionista". En último término, la crítica no es sólo un problema del conocimiento, sino de la conciencia y del espíritu y por lo tanto, un problema personal.

En 1940, por primera vez se pide consejo a Justino Fernández, para seleccionar parte de la obra artística que México iba a exponer en el $\mathrm{Pa}$ bellón Mexicano de la Feria Mundial de Nueva York, el evento tuvo un gran éxito. Esta tarea no sólo sirvió para colocar el arte mexicano en un sitio destacado dentro del contexto del arte universal, también fue fundamental para Justino Fernández. Comisionado por el secretario de Economía, para encargarse de dicho pabellón, tuvo oportunidad de acercarse a las obras maestras del arte universal y a las pinturas murales de artistas mexicanos realizadas en Nueva York, como el fresco "Dive Bomber" que José Clemente Orozco pintó en el Museo de Arte Moderno de esa ciudad.

Más adelante, en 1942, Justino Fernández señalaría, en el preámbulo de su libro José Clemente Orozco. Forma $e$ ided, ${ }^{2}$ el alcance que para él tuvo su primera salida de México:

Una circunstancia favorable, la de haber sido comisionado por el entonces Secretario de la Economía Nacional, don Efraín Buenrostro, y auxiliado por el jefe del Departamento Administrativo de aquella Secretaría, don. Felipe Teixidor, para encargarme del Pabelión Mexicano en la Feria Mun-

2 Fernández, Justino. José Clemente Orozco. Forma e idea. México. Ed. Porrúa, 1942. 
dial de Nueva York el afio de 1940 me permitió ver las pinturas originales que el artista mexicano - Orozco- ha realizado en el país vecino.

También en 1940, Justino Fernández fue colaborador de don Manuel Toussaint, para escoger las piezas de arte colonial que se exhibieron en la exposición "Veinte Siglos de Arte Mexicano", que tuvo lugar en el Museo de Arte Moderno de Nueva York. Primera exhibición monumental que abarcó todos los campos del arte mexicano, organizada por el gobierno de México y dicho museo. Gracias al catálogo que conjuntamente publicaron el Museo de Arte Moderno de Nueva York y el Instituto de Antropología e Historia de México, podemos damos cuenta de que, con muy buen criterio, Justino Fernández optó por los ejemplos sobresalientes, de las distintas etapas de nuestro arte colonial.

Una de las primeras consultas relacionadas con la copia de una estatua, data del año de 1946. El ingeniero Jesús Montúfar Gómez, presidente del Comité Pro-Monumento a Juan Ruiz de Alarcón en Taxco, solicitó permiso del Director de la Biblioteca Nacional para sacar una reproducción en piedra de la estatua que de este dramaturgo existe en el salón de la Biblioteca. Su petición fue turnada a las autoridades universitarias, las que a su vez la pasaron al Instituto de Investigaciones Estéticas. El dictamen lo firma Justino Fernández. Da primeramente su opinión de quién es el posible autor de la estatua. En su parecer es obra de alguno de los discípulos del notable escultor catalán Manuel Vilar, ya que ellos se encargaron de ejecutar las esculturas que se encuentran en la Biblioteca Nacional. Todos, afirma, tienen el mismo estilo, por lo que no puede precisarse cuál de esos discípulos fue su autor. Señala, además, que la figura es de buena proporción y está bien realizada dentro del concepto de la escultura de su tiempo, a pesar de que adolece de:

Dos defectos que la hacen desmerecer, uno es la desproporción de la mano extendida y otro la posición de la figura que se encuentra de pie y un tanto echada para atrás, quizá para equilibrarla puesto que la joroba del representado hubiese pesado mucho si se coloca en su posición natural.

En seguida comenta que la escultura "tiene dignidad" y que vale la pena reproducirla si se corrigen con tino esas fallas. Pero, poco afectó a que las manifestaciones artísticas de otras épocas fueran reproducidas, aconsejó dar la oportunidad a algún escultor contemporáneo, de realizar una nueva y original interpretación del autor de la Verdad sospechosa, pues muchas veces - patentizó- que si bien el prestigio de la tradición 
más remota es respetable, igualmente lo es la más reciente, la que acabamos de pasar y que va poblando nuestro espíritu de recuerdo, y que la misma validez que las del pasado tienen las muestras de arte de nuestro momento.

Su parecer fue respetado. El proyecto de copiar la estatua no se llevó al cabo. Muchos años después, en 1973, el pueblo de Taxco rindíb homenaje al poeta al erigirle un pequeño busto, obra de el escultor Peraza. El bronce se colocó en una placita cercana a la casa en que se dice nació Juan Ruiz de Alarcón.

En marzo de 1948 se le solicitó un dictamen sobre el manuscrito original titulado: La póstuma peripecia de Goya, de José Almoina. La respuesta de Justino Femández fue entusiasta. Consideró que la obra era digna de ser editada por el Instituto de Investigaciones Estéticas; insistió en que su publicación debía tomarse con vivo interés, pues el autor "posee antecedentes que lo acreditan como un intelectual de calidad y su libro Erasmismo en México es buena prueba de ello". Y declaró que La póstuma peripecia de Goya era un trabajo útil e interesante al que lo enriquecían "valiosos documentos inéditos". Gracias a ese informe, el original de José Almoina fue publicado por el Instituto de Investigaciones Estéticas en 1949.

La edición, además de ser una novedad, resultó de gran importancia para los estudiosos y admiradores de la obra del gran pintor español, al dar en ella minuciosa cuenta de un tema no tratado antes: "Ios entierros de Goya".

En 1952, invitado por la Secretaría de Relaciones Exteriores y el Instituto de Bellas Artes de México, colaboró en la Exposición de Arte Mexicano en París. La experiencia adquirida por Justino Fernández en 1940, hacía indispensable su ayuda en esta segunda exposición de carácter monumental.

Aunque esta exhibición de París fue mayor en número y en extensión, la selección de los objetos que iban a representar a México, se hizo por razón natural con más cuidado y cada uno de los periodos del arte mexicano quedó mejor ilustrado que en la Exposición de Nueva York de 1940. Justino Fernández lleno de entusiasmo no desdeñó intervenir en cualquier trabajo que redundara en beneficio del lucimiento de dicha exhibición.

Una vez en París, consciente del interés que había en México por conocer el impacto y resultados que esa exposición iba a causar en Europa, envió dos artículos que publicó el periódico El Universal: "El Arte en París" (19 de mayo) y "La Exposición de Arte Mexicano en París" (2 de 
junio) en los que daba cuenta de la forma en que había quedado instalada, lo acertado de la selección de los objetos artísticos.

Toda la planta del Museo Nacional de Arte Moderno, un vasto edificio, contiene las colecciones enviadas por México y que se han instalado en la serie de enormes salones que, uno tras otro en ordenada secuencia van revelando al visitante todas aquellas expresiones de arte que nuestro país ha producido en veinte siglos, digamos, para no exagerar.

En su primer artículo aparte de comentar su buena fortuna que lo hizo testigo de las dos "mejores exposiciones de arte que México ha enviado al extranjero en nuestro tiempo", describe el contingente de pinturas contemporáneas enviadas a París, la colocación que se dio a las mismas, y se disculpa por ocuparse primero de ellas:

Permítaseme invertir, por así decirlo, el orden de la historia y hablar en primer lugar de la pintura contemporánea; ya que, como decía Baudelaire, "tengo la pintura en los nervios".

Indica que cuatro grandes salones se destinaron, respectivamente, a Orozco, Rivera, Siqueiros y Tamayo, que la colección de sus obras allí presentadas es excelente y que en otras salas iguales a las anteriores están representados pintores mexicanos como el Dr. Atl, Goitia, Montenegro, Frida Kahlo.

En el segundo escrito reconoce la importante intervención de Fernando Gamboa:

La Exposición de Arte Mexicano, en el Museo Nacional de Arte Moderno ha sido planeada e instalada con gran perfección por Fernando Gamboa.

Finaliza incluyendo y glosando algunos de los muchos elogiosos comentarios que en torno a la exposición aparecieron en la prensa periódica parisina:

Antes de abrirse la Exposición ya aparecieron artículos y notas. El día 7 en Combat H. Rosenhelm habló de lo necesario y fructuoso que es para la educación de los pueblos la comunicación visual directa; hizo un elogio al Instituto de Bellas Artes; señaló el carácter único de los objetos; observó que el hombre social se manifiesta a través del arte mexicano y en especial en las obras del periodo modemo; y concluyó diciendo que la exposición no tiene paralelo. 
El día mismo de la apertura, el 20, un artículo de G. J. Gros en Ce Matin tenía por título: "Suntuoso, violento y quizá monstruoso, tal es el arte mexicano, del cual se abrió hoy una espléndida exposición en el Museo Na. cional de Arte Modemo." Decía Gros: que jamás un conjunto de arte nacional había dado de un país tan curiosa y extraña imagen... "todo crea un ambiente que se diria ser de otro planeta"; que Orozco, Rivera, Siqueiros y Tamayo son dignos descendientes de sus ancestros; y conclúa diciendo: que la exposición es de talla original, en el sentido más noble de la palabra.

En Le Figaro, el día 20. Andié Warnod dijo que la exposición daba una nota desconocida; que está organizada lógica y claramente; que el siglo xx aporta una nota más grave, más importante; que Orozco, Rivera, Siqueiros y Tamayo son grandes artistas de rango internacional y que se tenía una visión de conjunto de la pintura mexicana de hoy, que tiene un lugar importante.

La exposición no tiene precedente, dijo Gustavo Joly en L'Aurore, el día 21 , y añadio: que tiene una originalidad y una fuerza extraordinaria: que es el acontecimiento de la temporada. Habló de las artes de los distintos periodos elogiosamente, así como de los frescos monumentales.

El eminente Jacques Soustelle, gran conocedor y amigo de México, publicó un artículo en Carrefour, el dia 21, en que dijo: que el conjunto expuesto es el primero de tal importancia y de tal riqueza que ha sido posible contemplar en París: que es un esfuerzo sin precedentes; que encontrar reunidas tantas obras de las culturas antiguas es una rara fortuna que quizá no vuelva a acontecer en mucho tiempo: que en el periodo colonial no sucumbió la vitalidad artística del pueblo; que no será posible comprender la importancia del movimiento de pintura contemporánea sin conocer los frescos de Rivera en Chapingo y los de Orozco en la Preparatoria; que en el arte popular hay la persistencia de lo macabro, como en Posada.

Justino Fernández, como gran universitario que fue, dedicb mucho de su tiempo a la preservación del legado artístico de la Universidad. Las autoridades universitarias siempre solicitaron su opinión acerca de: compra de bibliotecas; publicaciones de libros relacionados con el arte; calidad de pintores y escultores cuyas obras se deseaba exhibir en las galerías de la Universidad; autenticidad y valor de esculturas pertenecientes al patrimonio de la misma; adquisición de obras de arte con las cuales se acrecentara su acervo; el talento y habilidad de artistas a quienes se habían encargado retratos de universitarios ilustres, destinados a omamentar y honrar algunos de los planteles de nuestra máxima Casa de Estudios.

Un caso muy notable de la actuación de Justino Fernández, como consultor de las autoridades universitarias, sobre un monumento artístico 
DOI: http://dx.doi.org/10.22201/iie.18703062e.1973.42.977

\section{ILUSTRACIONES}


DOI: http://dx.doi.org/10.22201/iie.18703062e.1973.42.977 
DOI: http://dx.doi.org/10.22201/iie.18703062e.1973.42.977

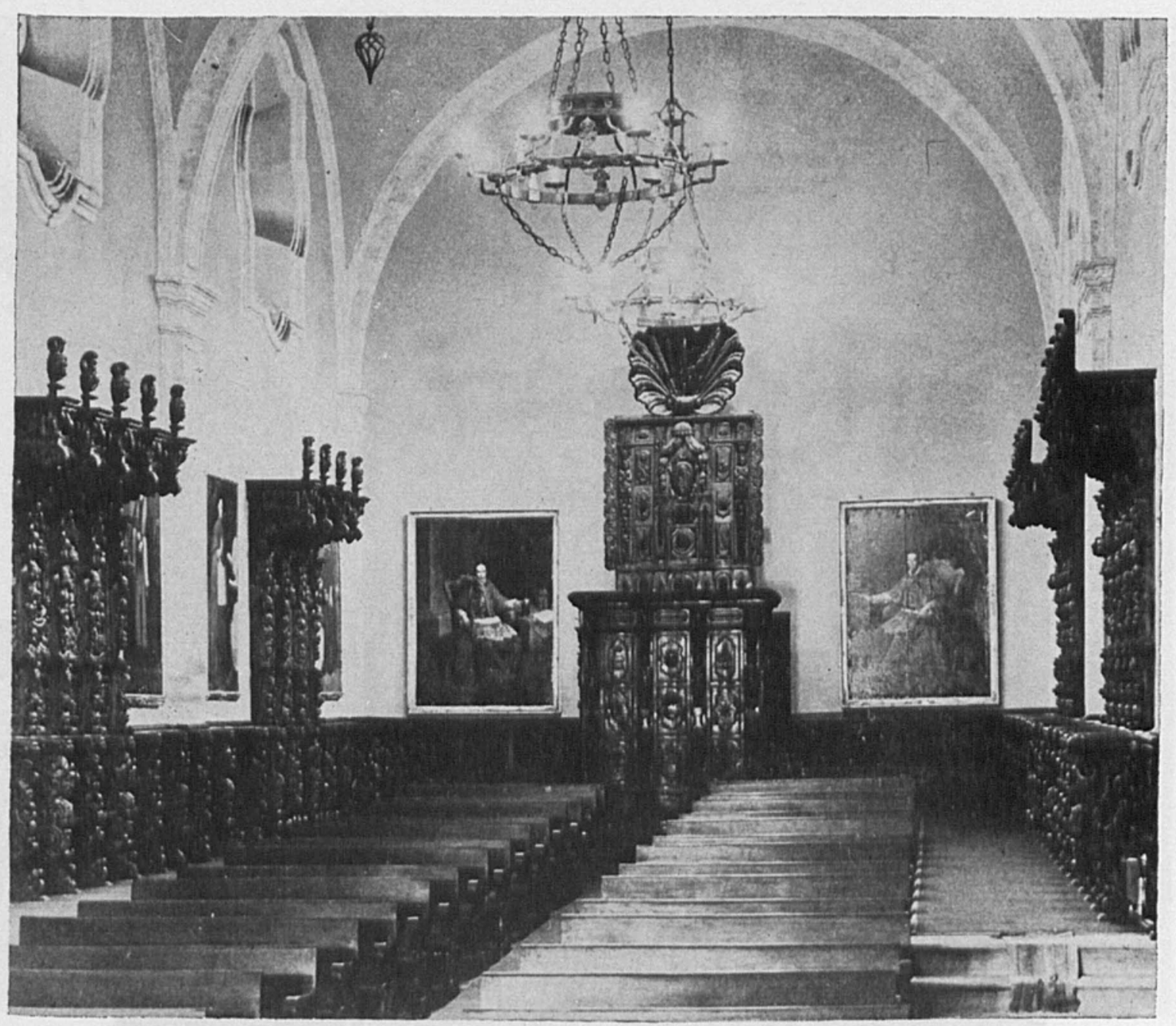

1. Vista del fondo del salón "El Generalito". 
DOI: http://dx.doi.org/10.22201/iie.18703062e.1973.42.977

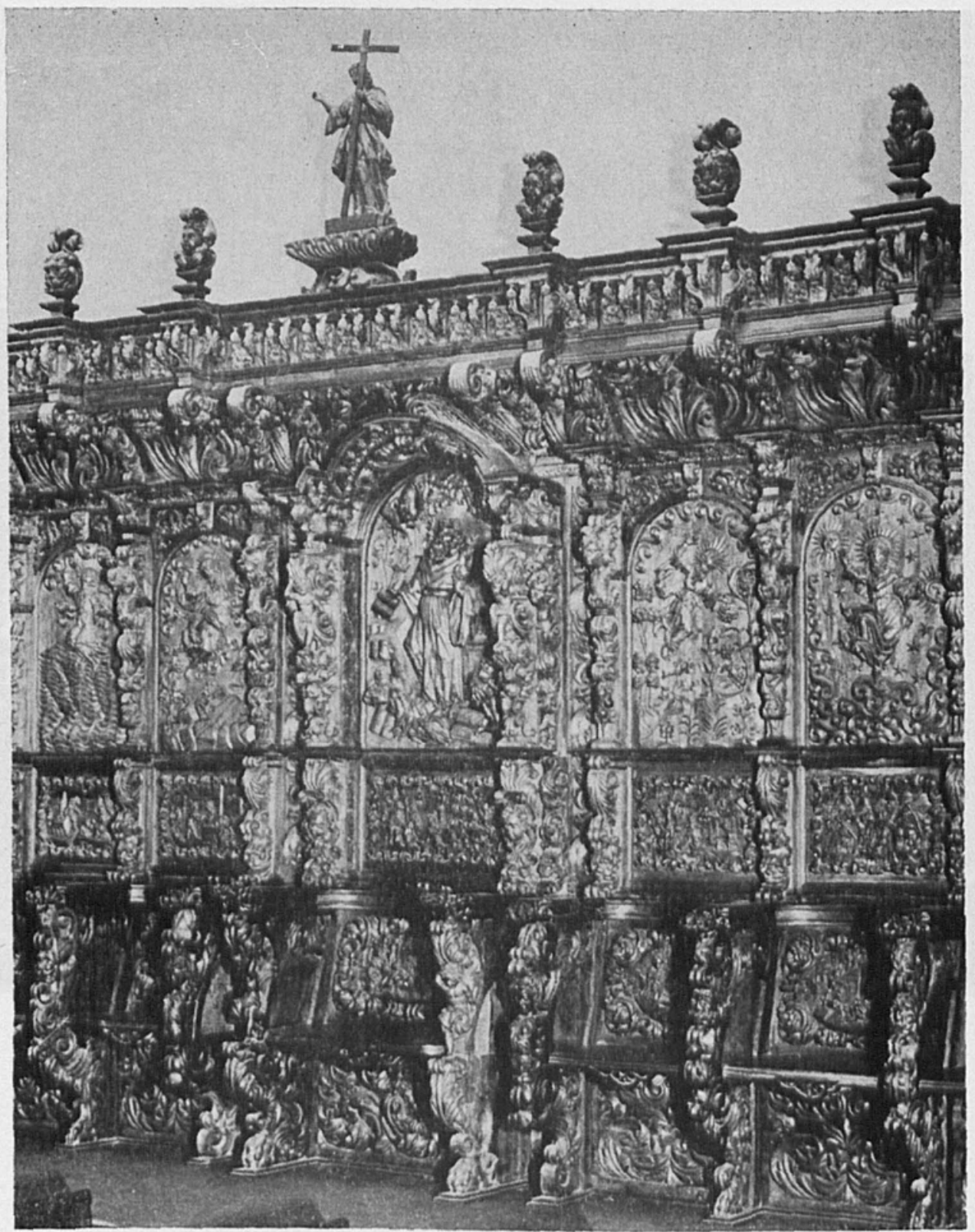

2. Parte central de la Sillería de San Agustín. Silla del Prior. Libro del Génesis. 


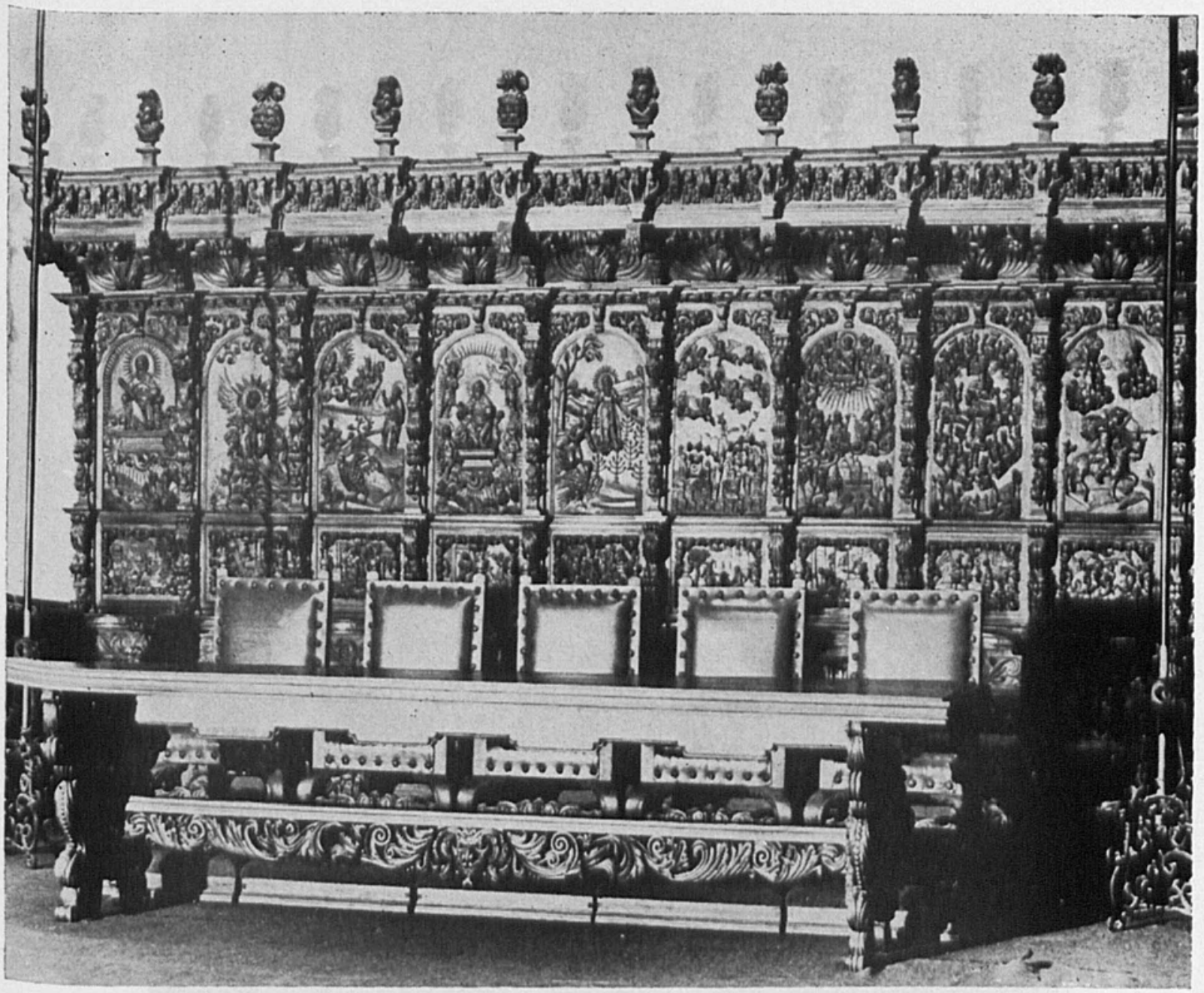

3. Sillería del Convento de San Agustín en "El Generalito". Libro del Apocalipsis. Cap. IV. 
DOI: http://dx.doi.org/10.22201/iie.18703062e.1973.42.977

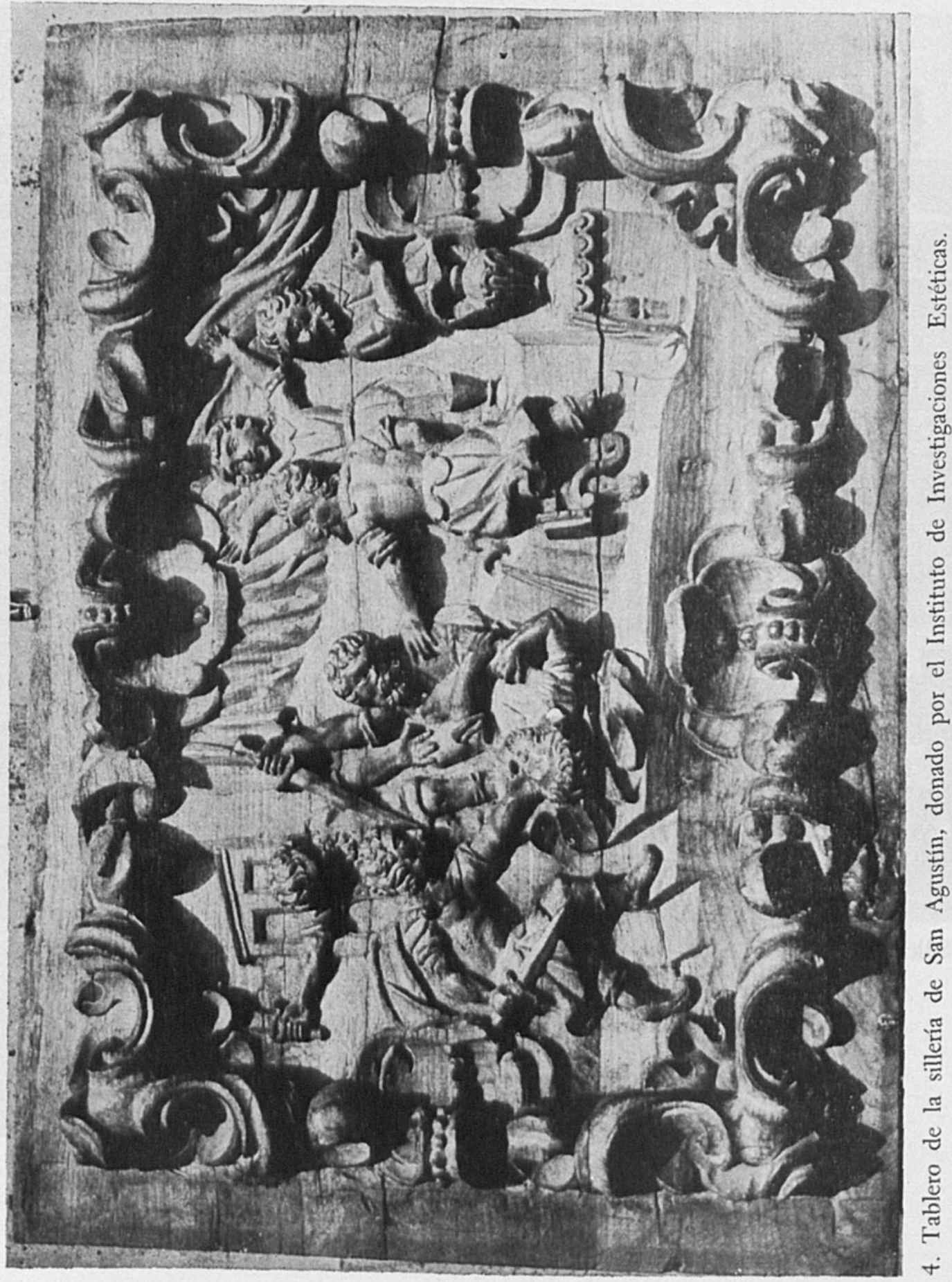


DOI: http://dx.doi.org/10.22201/iie.18703062e.1973.42.977

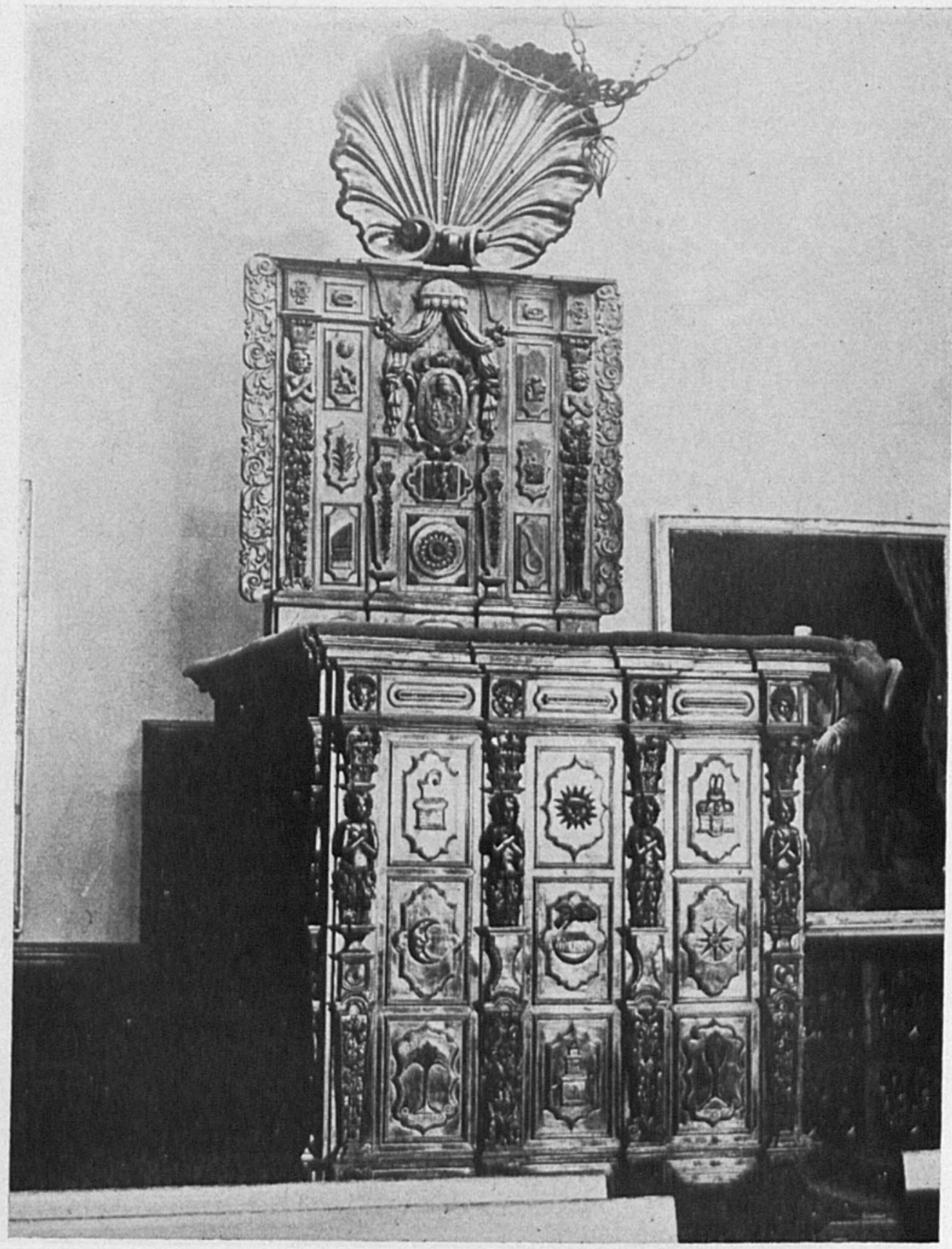

5. Cátedra de el antiguo colegio de San Ildefonso. 
DOI: http://dx.doi.org/10.22201/iie.18703062e.1973.42.977

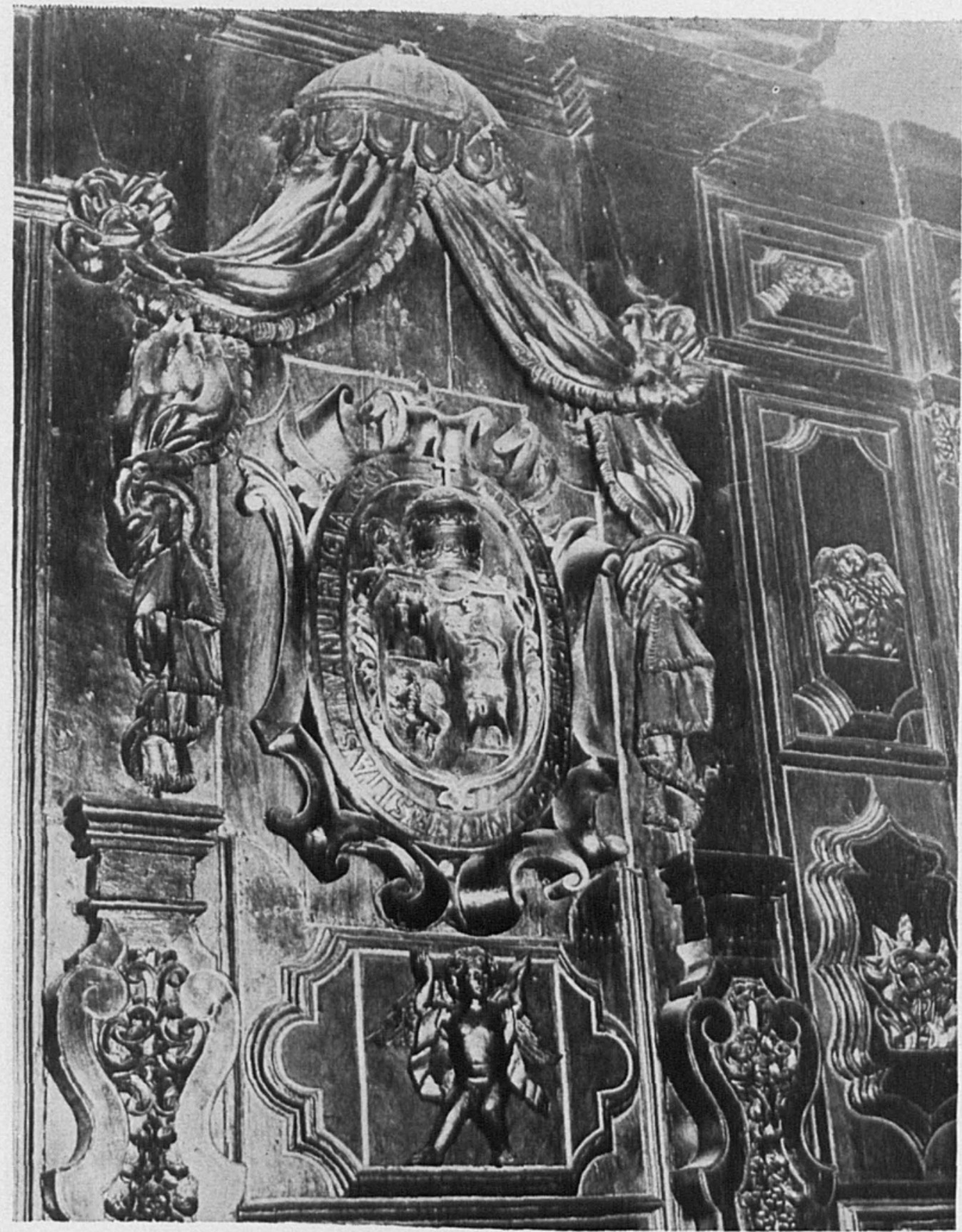

6. Escudo de la cátedra. 
DOI: http://dx.doi.org/10.22201/iie.18703062e.1973.42.977

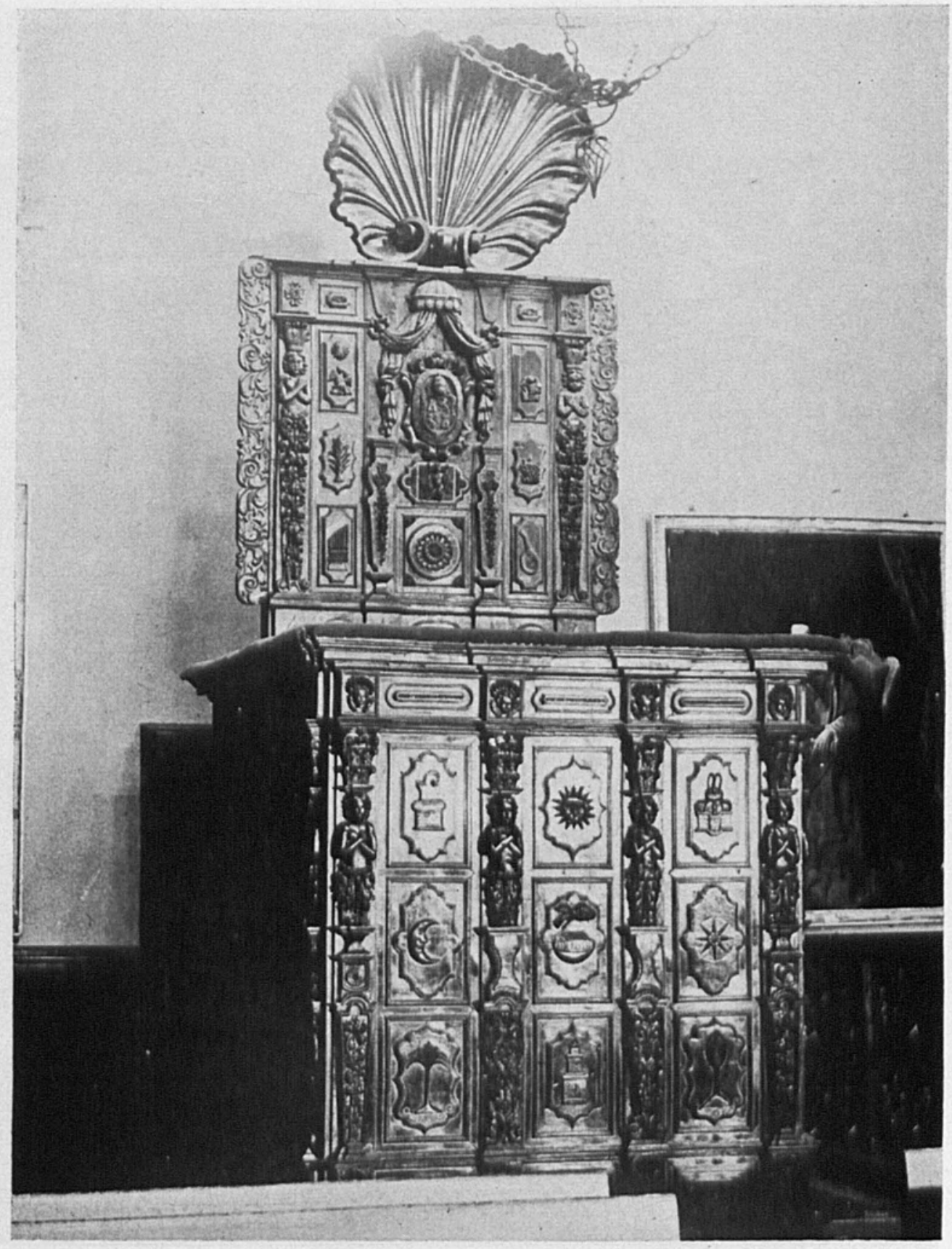

5. Cátedra de el antiguo colegio de San Ildefonso. 
DOI: http://dx.doi.org/10.22201/iie.18703062e.1973.42.977

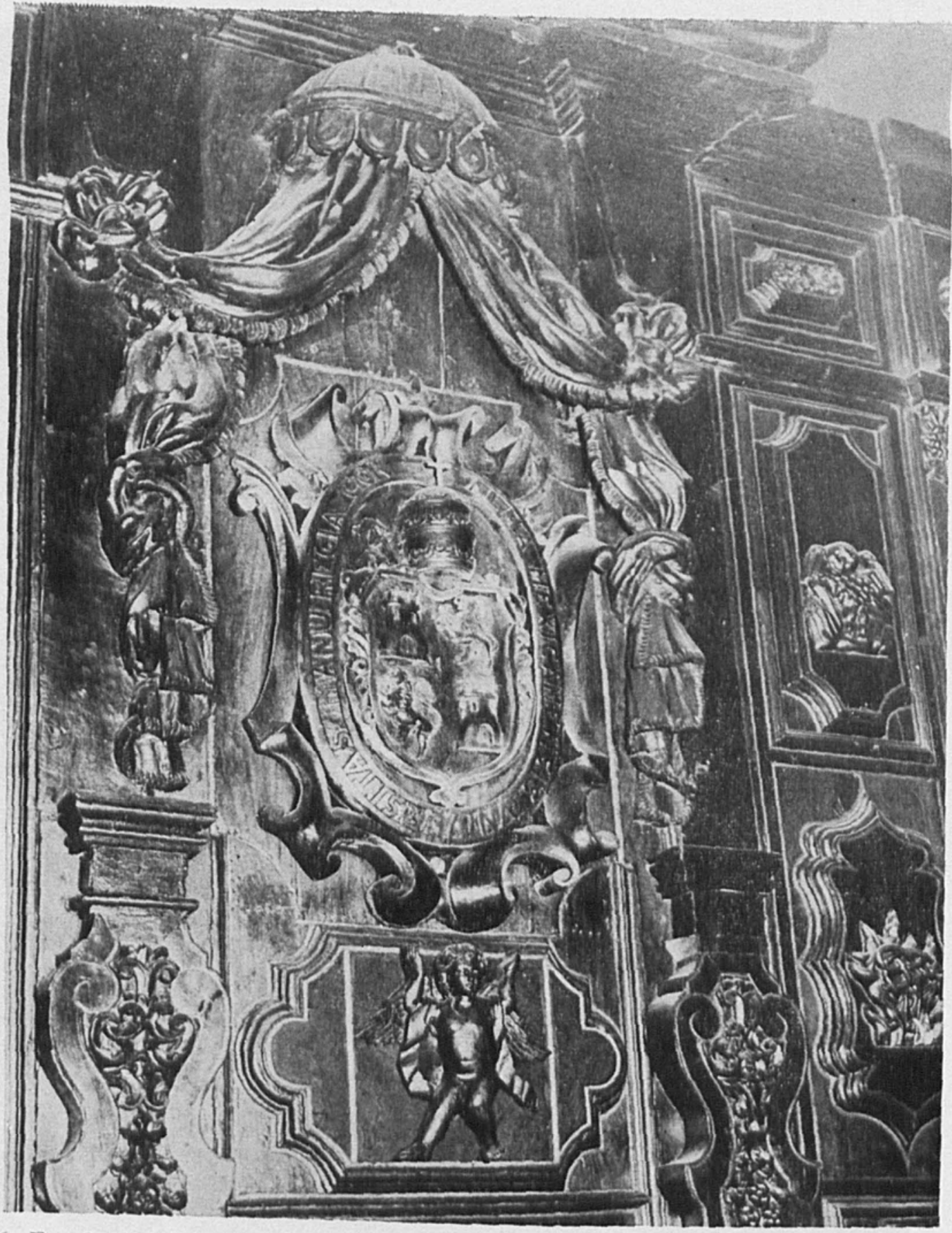

6. Escudo de la cátedra. 
de su patrimonio lo constituye la restauración del salón de actos de la Escuela Nacional Preparatoria y de la sillería que perteneció al templo de San Agustín.

El año de 1954, se requirió la intervención de Justino Fernández como consejero para vigilar las obras de restauración del salón de actos de la Escuela Nacional Preparatoria.

Este bello edificio colonial aúna a la grandiosidad de su fábrica, otras obras de arte excepcionales, como son las pinturas murales de José Clemente Orozco y Diego Rivera. También se encuentra en ella la magnífica sillería del coro del convento de San Agustín, una de las más hermosas de América, trasladada a esa Escuela en 1890 gracias a las gestiones del entonces director Vidal Castañeda y Nájera. El Siglo XIX, del 7 de octubre de 1890, se encargó de hacer pública esa importante adquisición de la Escuela Nacional Preparatoria:

El señor Castafieda y Nájera, director de la Preparatoria, consiguió que el gobiemo le cediera la admirable sillería que perteneció al convento de San Agustín. Ostentan las sillas entallados perfectos, los más notables pasajes bíblicos, siendo considerados los muebles como una obra de arte de inestimable valor. El clero ofreció en alguna época al gobierno treinta mil pesos por la sillería, dándole, además, la magnífica de Catedral; pero el gobiemo quiso cederla y pasará a ser principal adomo del salón de actos del plantel a que nos hemos referido...

El acomodo y restauración de la sillería de San Agustín, se hizo en el Salón General de la Escuela, llamado tradicionalmente, hasta nuestros días, "El Generalito". La tarea llevó varios años a don Nicolás Fuentes, viejo y excelente empleado de la Preparatoria, ${ }^{3}$ y la sillería quedo instalada para el año de 1895.

El paso del tiempo y el mal trato de que fue objeto la sillería por parte de los alumnos, le ocasionaron otros desperfectos y tuvo que ser restaurada pricipalmente en el año de 1933, por el escultor Guillermo Toussaint, maestro de escultura de la Escuela de Artes Plásticas.

El Instituto de Investigaciones Estéticas, desde su fundación como Laboratorio de Arte en 1935, había mostrado especial interés por esa joya colonial. Manuel Toussaint, director del Instituto por aquellos años, comisionó a los investigadores Rafael García Granados para que identificaran las escenas bíblicas de los tableros de la sillería, y Justino Fernández

3 Rojas Garcidueñas, José. El Antiguo Colegio de San Ildefonso. México. UNAM, 1951, p. 61. 
para que hiciera una serie de dibujos de la misma. Como resultado de esos trabajos, el Instituto publicó en 1941, una monografía monumental ilustrada con los dibujos de Justino Fernández y fotografías de Dolores Alvarez Bravo. De esta manera, el Instituto cumplía una de sus principales finalidades, el investigar y difundir los valores del arte mexicano.

Por el descuido y falta de sensibilidad de algunas autoridades preparatorianas el salón de actos, con su inapreciable sillería, quedó convertido en bodega. En 1946 nuevamente se trató de reparar "El Generalito" y la sillería. Como constancia de ese intento, en los archivos del Instituto de Investigaciones Estéticas se conserva el presupuesto que en esa ocasión presentó el escultor Guillermo Toussaint, sin embargo, no pudo llevarse a efecto esa restauración.

Para 1953, la Generación de preparatorianos "1920-1924" quiso utilizar ese recinto para hacer un homenaje al maestro Erasmo Castellanos Quinto $y$, al encontrar el salón en pésimas condiciones, el grupo encabezado por el licenciado Raúl Noriega, decidió reconstruir no sólo la sillería, sino todo "El Generalito". Para la empresa contaron con el apoyo de las autoridades universitarias y del secretario de Hacienda y Crédito Público, licenciado Antonio Carrillo Flores.

La idea de los miembros de la Generación "1920-1924", era devolver a la mencionada aula su antigua dignidad para que en ella pudieran celebrarse ceremonias y actos académicos, como aquel primero y muy solemne efectuado el 17 de septiembre de 1895, durante el cual, en un brillante discurso, don Ezequiel A. Chávez vertiera ideas trascendentales para la historia de la educación en México.

Para realizar la tarea de reconstrucción de "El Generalito" se formó un comité que quedó integrado por los licenciados Raúl Pous Ortiz, director general de Enseñanza Preparatoria; Raúl Noriega, oficial mayor de la Secretaría de Hacienda y el doctor Justino Fernández, comisionado por el Instituto de Investigaciones Estéticas, para el asesoramiento de esos trabajos. No se podía haber pensado en un consejero más competente. La restauración se inició en 1954, y Justino Fernández acometió esta obra, con el ímpetu y la meticulosidad que lo caracterizaban; la reconstitución de la sillería fue encomendada al maestro tallista Lázaro López Silva, y los arreglos del recinto quedaron primero bajo la dirección del ingeniero Alfonso Gallardo y después del señor Eugenio Moreno, de quien más tarde Justino Fernández diria que "con toda eficiencia cumplió su cometido". 
Los trabajos de renovación no fueron fáciles. La sillería estaba muy deteriorada, la restauración, por lo tanto tardó varios años, durante los cuales la vigilante mirada de Justino Fernández estuvo pendiente de los detalles más mínimos. El cuidadoso empeño de Justino Fernández puede seguirse paso a paso a través de su copiosa correspondencia sostenida con don Manuel Toussaint, con el doctor Efrén del Pozo, entonces secretario general de la Universidad y con los miembros del Comité de Restauración. En esa amplia correspondencia se encuentra el relato minucioso de los progresos y cambios efectuados en la reconstrucción, sus consejos para el nuevo decorado del recinto; colorido de alfombras y muros; iluminación; colocación del mobiliario integrado por la sillería, las bancas necesarias y la cátedra, ésa sí perteneciente al antiguo Colegio de San Ildefonso, esta última es una obra barroca posterior a la sillería, y otro bello ejemplo de nuestro arte colonial. "De carácter menos rico y preciosista pero majestuosa en su conjunto" al decir de José Rojas Garcidueñas, quien además señala que, "esa cátedra tiene exactamente el mismo carácter plástico que la obra arquitectónica de San Ildefonso"."

En casi todas las comunicaciones dirigidas a las autoridades univers:tarias, reitera Justino Fernández la importancia de que los encargados de la obra tomen "todas las precauciones posibles para proteger tanto la sillería del salón como los frescos de Orozco, cubriendo aquélla y aislándola y no golpeando en las paredes que tienen frescos por el lado del patio".

Además de las precauciones señaladas, Justino Fernández consideró muy pertinente que se reglamentara el uso del salón con objeto de proteger la sillería. En vista del desprecio que habían mostrado los alumnos de varias generaciones respecto a esa joya del arte colonial y a las pinturas murales, sugería que se imprimieran unos folletos en los que se explicara el interés y valor de esas obras de arte, folletos que deberían repartirse cada semestre entre el estudiantado preparatoriano. Desafortunadamente esas recomendaciones no fueron atendidas, y hoy, más que nunca sigue siendo necesario, el reiterar la conveniencia de elaborar ese cuaderno, pues el menosprecio se ha tornado en grave vandalismo.

En julio de 1957, Justino Fernández, a nombre propio y de los demás miembros del Instituto de Investigaciones Estéticas, hizo donación a la Escuela Preparatoria de un pequeño relieve tallado en madera, que pertenecía a la sillería, y lo envió al rector con estas líneas:

4 Op. cit., p. 62. 
En este Instituto se encuentra desde hace muchos años, un pequeño relieve en madera tallada, que representa una escena bíblica, y que pertenece a la antigua sillería del Coro de San Agustín de México... Parece que cuando la sillería se trasladó en el siglo pasado al lugar que ahora ocupa no hubo sitio para algunos de los sillones, pues fue necesario adaptarla al nuevo lugar. Así algunas piezas quedaron sueitas. Varias de las tablas se conservan en el Museo Nacional de Historia, en Chapultepec, y este Instituto conserva la ya mencionada ... adjunta encontrará usted una fotografía.

Tanto el maestro entallador Lázaro Lopez, quien se ha encargado de completar algunas partes faltantes de la sillería, y yo, hemos observado que falta algún tablero y que en ese lugar puede colocarse el que conserva este Instituto, de manera que es a todas luces conveniente que se le dé su sitio en la sillería, pues no hay razón para que se conserve suelto y por separado. El tablero fue restituido.

A pesar de todos los intentos de apresurar las faenas, la restauración de "El Generalito" se prolongó y complico, debido a la urgencia de extender las reparaciones al patio y crujías en que se encuentra este salón de actos. Ya en 1776, el edificio había resentido graves daños ocasionados por fuertes temblores de ticrra. En ese mismo año las autoridades alonsiacas comisionaron para reparar esos desperfectos al arquitecto Guerrero y Torres, 5 autor de monumentos tan bellos como la casa de los condes de Santiago de Calimaya y la de los marqueses de San Mateo de Valparaíso. Guerrero y Torres realizó una buena labor de reconstrucción, pero resulta indudable que desde entonces quedaron resentidos los cimientos del edificio, daño al que se añadieron más perjuicios con las reformas hechas a la construcción en la segunda mitad del siglo pasado, al establecerse en San Ildefonso la Escuela Nacional Preparatoria.

También los frescos de José Clemente Orozco, durante esas reparaciones al antiguo edificio de San Ildefonso, fueron objeto de gran preocupación para Justino Fernández, admirador y divulgador de la obra de este artista. Se dirigió al secretario general de la Universidad, para hacerle ver la conveniencia de consolidar y proteger esas pinturas murales, tarea para la que recomendaba al profesor Guillermo Sánchez Lemus, experimentado restaurador que se encontraba restaurando con gran talento los frescos de Diego Rivera en Chapingo.

Poco tiempo después vino a México el profesor H. Ruhemann, restaurador de pinturas de la National Gallery de Londres; las autoridades universitarias lo pusieron en contacto con Justino Fernández y en su

5 Op. cit., p. 44. 
compañía conoció la obra de nuestros grandes muralistas. Pudo darse cuenta de la habilidad del profesor Sánchez Lemus como restaurador. A su regreso a Inglaterra el profesor Ruhemann envió una carta a Justino Fernández, llena de entusiasmo por el arte mexicano. Acerca de la destreza del profesor Sánchez Lemus; su opinión fue por demás halagadora y recomendó a dicho profesor que se uniera a la Sociedad Internacional de Restauración. Ruhemann coincide con Justino Fernández en que se considere cuanto antes el proyecto de Sánchez Lemus para el arreglo de las pinturas murales de la Preparatoria. Con fecha 6 de mayo de 1957, Justino Fernández envió un resumen de esa carta al doctor Efrén del Pozo, subrayando los puntos más importantes contenidos en ella.

La reparación de las pinturas de Orozco se inició hasta enero de 1958, durante ese año se trabajó sin cesar en los arreglos de San Idelfonso. EF doctor Fernández con fecha 21 de noviembre de ese año, mandó a la Rectoría un escrito en el que informa de los progresos que se han hecho, indicando que las obras en "El Generalito" están muy adelantadas. Añade que es necesario prohibir los juegos de pelota en el patio grande donde están las pinturas, y que se nombre al maestro Lázaro López Silva conservador de las obras de arte de la Preparatoria, "pues de otra manera se habrán hecho gastos inútiles tanto en la restauración de los frescos como del mencionado salón". Su petición encuentra respuesta hasta abril de 1960, en que el maestro López es nombrado, junto con dos ayudantes, custodio de dichas obras de arte.

En junio de 1960 Justino Fernández envía al rector y al secretariogeneral de la Universidad, una larga y pormenorizada reseña de el estado. en que se encuentran las reconstrucciones en la Escuela Preparatoria, escrito dividido en tres partes: obras de arquitectura; de restauración de: las pinturas murales, y de renovación de "El Generalito".

Los vastos conocimientos sobre arquitectura de Justino Fernández, de quien Francisco de la Maza dijo "que sin ser arquitecto sabe tanto o más que muchos titulados", lo capacitaban para apreciar o corregir las obras que se estaban llevando al cabo en San Ildefonso, y gracias a esa experiencia en arquitectura, declara en su informe que la labor de reconstrucción de la crujía oriental del patio grande que estaba casi terminada, era meritoria, aunque presentara algunos defectos:

... los techos de corredores y salones resultan un poco pesados, pues tienen traves de concreto intermedias innecesarias para imitar viguería, sin embargo los arquitectos proponen cubrizlas con madera y quizá mejore 
el efecto. Sea como sea todo ha mejorado notablemente y los salones quedaron en condiciones superiores a las que estaban.

Menciona como medida plausible el cambio de algunas piedras carcomidas de varias bases de columsas del patio; agrega que se deben levantar "lambrines de mampostería de piedra en los corredores en que se encuentran las pinturas murales, para dar a éstas un marco de mayor calidad". Habla de la conveniencia de que en el segundo piso. "se enmarque la pintura con una pilastra de piedra o bien se construya un arco que deje limitada esa parte - uno de los mejores fragmentos de la pintura de Orozco- 'Las Soldaderas', y visualmente separada del resto del corredor a la derecha", completándose el trabajo:

Con algún tipo de iluminación eléctrica sobre las columnas de los arcos, para que reflejen sobre las pinturas sin que se interpongan a la vista lámparas colgantes.

En cuanto a la protección de esas pinturas, menciona como la solución más adecuada:

Cerrar con rejas de fierro forjado los extremos de los corredores de los pisos superiores, ya que no es indispensable el paso de estudiantes.

Finaliza sus consideraciones sobre la reconstrucción arquitectónica, con la mención de que aún continúan sin atenderse el pavimento y la protección a los muros del cubo de entrada que se encuentran muy cuarteados, y en los cuales existen otros murales muy maltratados "que será necesario restaurar".

Respecto a las pinturas murales de José Clemente Orozco, que se hallan en el patio, se congratula de comunicar que han sufrido muy pocos daños durante las obras de reparación del edificio. En cuanto a los frescos ya restaurados y los del primer piso, en los que se estaba trabajando, opina que:

Lucen magníficos como no se veían desde que Orozco los pintó, pues si bien estaban terriblemente estropeados, el señor Sánchez Lemus ha llevado la obra con tan buen sentido y técnica apropiada que no podían quedar mejor.

El doctor Fernández felicita al profesor Sánchez Lemus y a las autoridades universitarias "por haber atendido a la restauración de obras de arte tan importantes", sin olvidarse de apuntar que: 
Aún queda por llevar a cabo la restauración de las pinturas del segundo piso, las del cubo de la entrada, las del muro del piso bajo que dan al poniente, donde están la escalera y las del muro de la escalera misma - de donde recomienda retirar - la ventana del descanso que es un vitral del siglo pasado que rompe la armonía y que restaurado puede colocarse en otro sitio adecuado.

\section{Al hablar de los arreglos en "El Generalito", detalla:}

La obra está prácticamente terminada y el salón luce como jamás se había visto, con la nueva disposición del estrado y de la cátedra, con la alfombra roja, con la sillería restaurada, con el lambrín y la boquilla de entrada que unifican el recinto, con los muros bien pintados color terracota que hacen lucir las formas arquitectónicas, con las pinturas y muros restaurados, con los candiles de fierro forjado. El salón es, hoy día una joya pulida sin igual y también aquí merecen felicitaciones cuantos han contribuido al buen éxito, especialmente el maestro Lázaro López, la Secretaría de Hacienda y las autoridades universitarias por haber atendido a la conservación de un legado artístico de suma importancia.

Termina su escrito haciendo hincapié en lo que tantas veces ha pedido: que además de que se prohíban los juegos de pelota en ese patio, lo cual es factible pues la Escuela tiene otros lugares apropiados para eso, es forzoso buscar la mejor forma para que el alumno entienda la trascendencia que tienen esas obras de arte y el respeto que merecen, por ejemplo, el colocar una placa de bronce al lado de los murales en que se dé noticia del valor que para la pintura mural mexicana tienen esos primeros frescos de José Clemente Orozco. Y al recapitular sobre los trabajos dice:

La conclusión a que se llega, si se pone en juego la imaginación, es que cl patio grande de la Escuela Preparatoria de San Ildefonso, restaurado, así como las pinturas murales de Orozco junto con el interior de "El Generalito", resulta una concentración de obras de arte de primera magnitud, magnífico legado cultural espiritual de varias épocas que las generaciones futuras deben conservar. Por ahora las obras realizadas deben ser un timbre de orgullo para las actuales autoridades universitarias y de la Escuela, pues eran urgentes y la atención que se ha dado es digna de encomio. En el futuro se tendrá que atender también al mejoramiento de la biblioteca.

Además de las restauraciones ya citadas, Justino Fernández atendió a la renovación de la biblioteca colocada en la antigua capilla del colegio alonsiaco, la que fue restaurada y decorada bajo su dirección; también 
orientó la creación de la nueva aula "Justo Sierra" y aprobó el nombramiento del maestro Angel Boliver, profesor de dibujo en la Preparatoria, para que ejecutara los retratos de algunos directores y maestros preparatorianos distinguidos, entre otros el de Justo Sierra, que serían colocados en esa sala. Estuvo también atento a lo que se hacía en el Anfiteatro Bolívar, donde se llevó a cabo una obra de limpieza y retoque: se mejoró la iluminación, la acústica, el mobiliario. Ahí nuevamente el celo de Justino Fernández se centró en la obra de arte: los murales de Diego Rivera. Ese interés se advierte en el escrito que con fecha 7 de agosto de 1962 envía al rector Ignacio Chávez, en cuyo inciso número 5 se lee:

El Anfiteatro Bolívar debe seguir conservando su carácter y siendo utilizado en eventos como los que hasta ahora ahí se han realizado y cuales quiera otros que pudieran efectuarse siempre que no sean necesarias decoraciones que oculten aun temporalmente el mural.

Con todas esas mejoras, se salvaban varias obras de arte y, sobre todo, parecía que se consolidaba definitivamente el bello edificio colonial de San Ildefonso y la parte de su anexo, que se terminó de construir en 1910, en donde se halla el Anfiteatro.

La inauguración solemne de "El Generalito" se efectuó hasta el 16 de febrero de 1962, y el día 25 de ese mismo mes se publicó en el periódico Novedades, en su sección "México en la Cultura", un artículo de Justino Fernández con la historia de la sillería y la siguiente descripción del salón ya restaurado:

La sillería está dispuesta sobre una plataforma que corre a lo largo de los muros del salón; parte de ella en grupos de cuatro sitiales que tienen elevados tableros que limitan en lo alto comisas sobre las cuales se levantan airo sos remates. Algunas partes no tienen los altos respaldos, pero en los espacios sobre ellas se han instalado pinturas con retratos de ilustres doctores del Colegio de San Ildefonso. En la parte central, frente a la entrada, un grupo de sitiales componen rico paño, al centro del cual se encuentra el tablero con la imagen de San Agustín, de excelente ejecución y talla.

Otro grupo más sobre el muro de la plataforma al fondo del salón, reservado al estrado, y en el extremo opuesto se levanta la cátedra, con su toma. voz en forma de concha, que es en sí obra de mérito, aunque de época posterior y diferente de la sillería. Al nivel del piso, en todo el espacio central, se han colocado bancas sencillas que armonizan con su color y calidad con la sillería. Los lambrines y el recubrimiento del arco de la entrada vinieron a unificar el recinto y a darle mayor riqueza al conjunto dentro de la severa sencillez que tiene, pues se trató de que la sillería luciera y no que otros elementos compitieran con ella. 
La amplitud de intereses de Justino Fernández y su actividad incansable durante esos años de trabajo en la Escuela Nacional Preparatoria, le permitieron atender a otras asesorías. Sus vastos conocimientos no sólo del arte mexicano, sino del arte universal, su fama como crítico de arte, lo atinado de sus juicios, le dieron notoriedad internacional y desde el extranjero se solicitó su ayuda y consejo.

En 1961, la entonces Asociación Antropológica de Guatemala solicitó la colaboración de Justino Fernández, cuando se pretendió restaurar algunas de las notables ruinas de Antigua, declarada monumento nacional desde 1944:

$\ldots$ Sabedores de su interés por la historia del arte hispanoamericano, no dudamos que le preocupará profundamente conocer acerca de los incesantes atentados que frecuentemente padecen nuestros monumentos históricos y artísticos.

... Nuestra decisión nació como consecuencia de un atentatorio proyecto de reconstrucción de las notables ruinas del templo de San Francisco en Antigua Guatemala, el cual, de realizarse, daría término a una de las ruinas más características de la antigua metrópoli centroamericana, a la vez que marcaría, indudablemente, la iniciación de parecidos proyectos en el resto. de dicha ciudad. Como parte de una campaña en defensa de dichos monumentos, nuestra entidad ha pensado que el solicitar la opinión de personas. cuya devoción y conocimiento sean reconocidos por su autoridad en historia del arte hispanoamericano, ayudarían grandemente a detener este proceso destructivo a la vez que nos proporcionarian valioso apoyo moral ...

La respuesta de adhesión de Justino Fernández a la Sociedad Antropológica no se hizo esperar:

Quedé enterado - dice- del proyecto para reconstruir las ruinas del Templo de San Francisco en Antigua Guatemala y no puedo menos de lamentar el peligro que existe de que se pierdan los valiosos vestigios de un pasado colonial que a todos nos interesa conservar. No sólo en este caso hay que hacer lo posible porque se conserve un monumento antiguo sino que en general es necesario evitar reconstrucciones en Antigua Guatemala, ya que con tan buen sentido fue declarada Monumento Nacional. Tanto en su país. como en el nuestro y en todos los de América se hace defender los monumentos artísticos e históricos que forman parte del gran legado de América a la cultura universal, pues de otro modo se irán perdiendo las características de nuestra historia y cultura que nos dan fisonomía propia.

Por fortuna para Guatemala esa campaña tuvo éxito y tanto el templa de San Francisco como otros monumentos de igual importancia fueron respetados. 
Dentro de la defensa del patrimonio artístico de México el rescate de monumentos coloniales no le fue ajeno, con sus oportunas intervenciones, logró que se salvaran algunos de ellos. En 1959, dio la batalla por la iglesia poblana de San Pablo de los Frailes y en 1960 se opuso a la ampliación de la calle de Tacuba.

La primitiva traza de la ciudad de México, con sus cambios y complicaciones posteriores le era muy conocida. Su experiencia sobre esta disciplina urbanística se remonta al año de 1938 en que colaboró con Manuel Toussaint y Federico Gómez de Orozco para publicar el libro Planos de la ciudad de México, siglos XVI y XVII, es por esto que, cuando en 1960 huibo la intención de ampliar las calles de Tacuba, su voz junto con la de intelectuales connotados de México, se dejó oír en contra de ese plan. Por suerte la prensa periódica apoyó esta oposición.

En una mesa redonda que tuvo lugar en la Asociación Mexicana de Periodistas, el 24 de febrero de 1960, discutieron esa ampliación los más destacados conocedores del arte, la historia y la arquitectura. Justino Fernández fue entrevistado unos días antes, el 10 de febrero, por el reportero de la revista Mañana. En ella sostuvo su oposición a que la calle de Tacuba, y con ella el centro de la ciudad, perdieran su fisonomía. Era inadmisible el pretexto que se daba para el ensanchamiento: los problemas del tránsito. En apoyo a su argumento el reportero hizo hincapié en que su opinión no podía tacharse de romántica, puesto que él era el representante de las más avanzadas teorías sobre el arte contemporáneo.

La ponencia que Justino Fernández presentó en la mesa redonda se publicó en el número 31 de los Anales del Instituto de Investigaciones Estéticas, con el título: "Urbanismo Culto vs Barbarie 'Funcional'."

Felizmente, Tacuba no fue ensanchada y las actuales autoridades han emprendido algunas reformas tendientes a ponderar los valores arquitectónicos del centro de la ciudad y a devolverle su tradición. Justino Fernández aprobaría algunos de esos cambios, pues están consignados en el último párrafo de su ponencia:

Puede uno imaginar ese núcleo antiguo con sus monumentos históricos y artísticos restaurados - y no sólo los coloniales sino los del siglo xrx- con la mala arquitectura vieja sustituida por otra moderna pero que armonice en alturas y materiales con la antigua, sin letreros que afeen las calles y avenidas; con alumbrado que haga lucir los monumentos; con ciertas calles para peatones exclusivamente; en fin con la limpieza y vigilancia necesarias. México daría así un ejemplo de cómo se puede conservar una ciudad antigua ligándola a su desarrollo moderno; seria un proyecto con grandeza y digno de aplauso. 
Tiempo después, inquietaría a Justino Fernández el olvido en que se encontraba una de las mejores obras escultóricas del siglo xIx, el Tlahuicole, del escultor catalán Manuel Vilar, quien fue profesor de la Acade mia de San Carlos en el siglo pasado. Esta escultura, la primera de la Academia con tema indigena antiguo, fue trasladada junto con otros vaciados en yeso, de la Escuela de Artes Plásticas a la Escuela de Arquitectura en la Ciudad Universitaria, en donde se colocaron en la bodega en condiciones poco adecuadas que podían ponerlos en peligro. Con este motivo, en septiembre de 1964, el doctor Fernández envió una carta al rector de la Universidad, doctor Ignacio Chávez, con copia para el profesor José Arellano Fisher, director de la Escuela de Artes Plásticas, en la que explicaba la importancia de la estatua y pedía que fuera vaciada en bronce:

...La escultura es un poco mayor que de tamaño natural y de excelcntc calidad en su modelado. Nunca ha sido vaciada en bronce... Ahora bien, en mi opinión, sería conveniente que dicha escultura fuera vaciada en bronce para salvarla de su destrucción y quedaría como ejemplo de la gran escul. tura clásica del siglo xix. Por su carácter heroico podría ser colocada en algún lugar de la Ciudad Universitaria. Me permito recomendar muy especialmente este asunto a su atención.

Su demanda fue atendida y, el 6 de noviembre de 1964, Justino Fernández enteraba al rector del presupucsto de veintiocho mil pesos qque a su juicio era justo, presentado por el profesor de la Escuela de Artes Plásticas Fernando Díaz L., para fundir en bronce el Tlahuicole. En esa carta hacía también la siguiente recomendación:

Convendría que el profesor Arellano Fischer nombrara una comisión de dos profesores de la Escuela de Artes Plásticas para que sean ellos quienes dictaminen sobre la obra ya terminada. Por mi parte también me interesa que quede lo mejor posible.

En el contrato que se firme con el profesor Díaz, creo que debe decirse en alguna cláusula que la fundición debe ser exactamente igual que el original y completa en todas sus partes y detalles. También que se cuide de no maltratar el vaciado en yeso - que se encuentra en la Facultad de Arquitcctura- y que se prestará para hacer la fundición.

La mala suerte que acompañó a Manuel Vilar, quien no logró ver ninguna de sus esculturas colocadas en los sitios para los que las ejecutó, o bien vaciadas en metal, parecía ligarse ahora al Tlahuicole; el profesor Díaz López, encargado de su fundición, falleció en forma repentina el 5 
de noviembre de 1964. Nuevos presupuestos fueron presentados en ese mismo año, pero la fundición quedó pendiente.

En junio de 1965, la Rectoría notifícó a Justino Fernández su acuerdo favorable para que el Tlahuicole se vaciara en bronce. El trabajo se confió al señor Vicente Barrón Rosas quien pidió treinta mil pesos como honorarios, y se comprometió a entregar el bronce en dos meses y medio. El profesor Arellano Fisher comisionó al escultor Manuel Silva Guerrero, profesor de la Escuela de Artes Plásticas, para que supervisara ese vaciado, cuyo molde en yeso fue entregado al fundidor pocos días despues.

Vicente Barrón Rosas no cumplió el trato. En julio de 1966, Justino Fernández hizo del conocimiento del nuevo rector, ingeniero Javier $\mathrm{Ba}$ rros Sierra, las gestiones realizadas con respecto al Tlahuicole, y le suplicó además que ordenara la averiguación de por qué esa estatua no estaba aún terminada.

Fue hasta septiembre de 1966, que el nuevo director de Artes Plásticas, Antonio Trejo Osorio, informó al doctor Fernández que la fundición del Tlahuicole estaba por concluirse; que la causa del retraso había sido la suspensión del pago de honorarios a Vicente Barrón Rosas, debido al conflicto estudaintil y a la renuncia del doctor Ignacio Chávez.

En abril de 1967, el Tlahuicole continuaba inconcluso, y los demás yesos del siglo xix que habían sido desalojados de las bodegas de Arquitectura, reclamaban la atención del doctor Fernández quien alarmado avisaba al rector:

Han sido dañados tan seriamente que será difícil su restauración. El caso es muy lamentable porque hasta hace poco tiempo se encontraban en una bodega, maltratados pero con posibilidad de ser restaurados, y alguien dio la orden de que se desalojara dicha bodega, lo cual se hizo de una manera bárbara.

El Instituto Nacional de Bellas Artes, institución a la que, por decreto presidencial, pertenecen esos yesos desde 1929, intervino rápidamente al rescate de las esculturas y Jesús Sotelo Inclán, subdirector técnico de ese instituto, en carta dirigida a Justino Fernández decía:

Nuevos informes del señor Moreno avisándonos del reciente traslado a otras dependencias de la Escuela Nacional de Arquitectura, de las esculturas de la antigua Academia de San Carlos, hecho esta vez en forma inapropiada, nos pone en la urgente situación de proceder a su recuperación inmediata y de suplicarle a usted se sirva comunicarlo al señor rector, solicitándole a la vez sea nombrado un miembro de ese Instituto a su digno cargo, para 
tener un asesor que participe con nosotros en la localización y recuperación de dichas esculturas.

El consejero nombrado, fue Salvador Moreno, investigador especial del Instituto de Investigaciones Estéticas, el que estaba escribiendo una monografía sobre Manuel Vilar. Este estudioso de nuestro siglo romántico, se entregó en cuerpo y alma a la tarea de localizar esas esculturas y, gracias a su diligencia, los yesos están hoy muy bien restaurados y vistosamente expuestos en apropiado marco: el Museo de San Carlos.

Las dos copias en bronce que se hicieron del Tlahuicole, no corrieron con igual suerte, una se encuentra en la bodega del museo universitario y la otra, que adomó por buen tiempo el segundo piso del Palacio de Bellas Artes, está ahora en su bodega, esperando tal vez el día en que se le traslade al Museo del siglo xix que esperamos muy pronto sea una realidad.

Con el último pago al fundidor, hecho el 19 de octubre de 1967 por la Universidad, a través de Justino Fernández, finalizaba victoriosamente esa larga batalla que tan buenos resultados había tenido, para la revalorización de nuestra olvidada escultura decimonónica.

Las pesquisas hechas para encontrar los yesos desalojados de las bodegas de la Escuela de Arquitectura, permitieron a Justino Fernández darse cuenta de que en la Universidad hay muchas obras de arte que requieren vigilancia permanente. El doctor Fernández sugirio al rector que se nombrara un conservador general de las obras de arte de la Universidad, y para este cargo de tanta responsabilidad recomendo al profesor Guiller. mo Sánchez Lemus, persona ampliamente capacitada, con estudios en el Instituto de Restauro de Roma, y quien tan diestramente había reparado los frescos de Orozco en la Preparatoria. Desgraciadamente ese puesto tan necesario no fue creado.

En 1967 otra vez se ve amenazada la integridad de los frescos de Orozco y de "El Generalito". A causa de nuevos hundimientos, el edificio de San Ildefonso sufre desperfectos de gravedad que requieren la restauración de "El Generalito". Justino Fernández profundamente alarmado informa al licenciado Fernando Solana, secretario general de la Universidad, que después de que "El Generalito" quedó tan dignamente restaurado en 1962 es forzoso tomar todas las precauciones posibles para no dañar de nuevo ese salón de actos:

Existen dos proyectos para las obras, uno anterior en el que se iban a amacizar las pilastras por la parte de abajo del piso sin tocar nada de el interior 
del salbn; pero recientemente ha surgido otro proyecto en que las obras se harían por la parte superior y en este caso se dañaría el salón y su contenido.

Por todo lo anterior suplico a usted que, de ser posible, haga una junta de técnicos en la que intervenga un arquitecto y que se estudien con mucho cuidado las ventajas e inconvenientes a que me he referido para que se tomen todas las precauciones necesarias de manera que no sea perjudicado el interior de "El Generalito".

El licenciado Solana estuvo de acuerdo en que se hiciera ese estudio.

Con fecha 18 de marzo de 1967 el arquitecto Juan O'Gorman escribió una carta a Justino Fernández para informarle lo "que acontece en el edificio de la Preparatoria de San Ildefonso, en las obras llevadas a cabo ahí, con respecto a los murales de José Clemente Orozco". Aparte le indica que es miembro con carácter honorario, de una comisión encargada de la conservación y restauro de los murales pintados en edificios públicos considerados como patrimonio de la nación, comisión que depende del Instituto Nacional de Bellas Artes.

Juan O'Gorman avisa a Justino Fernández que, durante los trabajos de reparación que se llevaron al cabo en el edificio de la Preparatoria, los murales de Fermín Revueltas y de Ramón Alba de la Canal, que se encuentran en el cubo de entrada, han sido prácticamente destruidos, pues están llenos de raspaduras, rayones y agujeros. Ante ese deterioro, la Comisión de Conservación y Restauro, se reunió con los ingenieros de la Universidad en el propio edificio de San Ildefonso, en donde se habló ampliamente sobre las medidas de protección necesarias.

Juan O'Gorman sigue insistiendo en que no se han tomado las medidas indicadas por la comisión:

Esta junta tuvo lugar hace seis semanas aproximadamente y antes de ayer que pasé por el edificio de San Ildefonso me encontré que no sólo no se ha hecho nada para proteger los murales, sino que como si se tratara de una broma, se ha comenzado la destrucción gratuita: ... En el fresco de la Trinchera de Orozco sobre el brazo de una de las figuras, a una altura aproximada de tres y medio metros, ya hay un agujero de una pulgada cuadrada de tamaño. El freso de la Maternidad está salpicado de cemento en toda su base y hasta unos tres metros de altura. Aparte de esto ya hay varias escurridas de agua con caliche sobre los murales de Jean Charlot y de Fernando Leal en el cubo de la escalera del mismo edificio.

... Yo te ruego que, en la medida de tus posibilidades por el respeto que tu opinión merece y por el alto cargo que tienes dentro de la Universidad, hagas lo que creas conveniente para detener esta destrucción, quizá incons- 
ciente, de una de las obras de arte que son de la máxima calidad que ha producido el genio humano, como con sabiduría tú lo has dicho muchas veces.

Justino Fernández envió copia de esa carta al rector, junto con el informe de su reciente visita a la Preparatoria, la que le habia permitido constatar lo mencionado por el arquitecto O'Gorman sobre los murales, "cuya protección y restauración es urgente". Además hizo esta salvedad:

... Este Instituto no tiene a su cargo la conservación de esas pinturas ni podría hacerlo porque sus finalidades son otras. Por otra parte, en este Instituto no hay peritos en restauración ni yo tengo la competencia para ello. Si hemos estado pendientes del estado en que se encuentran dichas obras de arte es por una responsabilidad moral y por conciencia de su valor.

En noviembre de 1967, el profesor Jesús Sotelo Inclán quiso estar en contacto constante con Justino Fernández para recibir sus sugerencias con respecto a las obras que se iban a llevar a cabo en la Preparatoria. Con ese motivo el doctor Fernández se reunió varias veces en el edificio de San Ildefonso con los miembros de la Comisión Asesora para la Restauración de la Pintura Mural y con los ingenieros encargados de la reconstrucción de esa escuela, para tratar de solucionar de la mejor forma los problemas que aquejaban a la Preparatoria y a las obras de arte que cse edificio alberga.

En abril de 1968 el ingeniero Armando Vega envió a Justino Fernández un estudio presentado por los doctores Raúl J. Marsal y Danicl Rcséndiz, del Instituto de Ingeniería, estudio en el que se indicaba la nccesidad de emprender las obras de reconstrucción inmediatamente, pues los daños en esa ala del edificio podrían ser mayores si no se atendían en seguida y afirmaban que era preciso que las obras se hicieran desde cI interior de "El Generalito". El ingeniero Vega aseguraba a Justino Fernández, que se tomarían todas las disposiciones que él indicara para preservar las obras de arte: la sillería y los murales de Orozco.

La respuesta de Justino Fernández al ingeniero Vega, con copia para el rector aclaraba:

Comprenderá usted que no tengo la competencia técnica para decidir en un sentido o en otro, ni para proponer métodos precisos de protección de la sillería, de los murales y del edificio mismo. Pero tratándose de obras de arte de primerísima importancia listórica y artística, pienso que debe adoptarse la solución que mejor garantice su conservación, independientemente 
del costo que pueda alcanzar, ya que todo valdría la pena si se salvan tanto los murales como la sillería y el edificio que es lo fundamental. Horroriza pensar en que la sillería quede abandonada, no sabemos donde, por mucho tiempo y que los murales de Orozco puedan sufrir desperfectos. Ya que parece que los procedimientos técnicos actuales disponen de muchas posibilidades, pienso que no se deben escatimar ni costos ni esfuerzos en este delicado problema de importancia que trasciende el interés nacional ya que son obras que pertenecen a la cultura universal.

Hasta principios de 1969 se iniciaron las obras de reconstrucción de San Ildefonso, Tomás Zurián, del Centro de Restauración del Instituto Nacional de Bellas Artes, aprobó las medidas de seguridad tomadas por el ingeniero Vega e hizo la advertencia de que ese centro haría inspecciones diversas para evitar problemas o accidentes no previstos.

De esa manera, gracias a la enérgica actitud de Justino Fernández, las obras de arte de la Preparatoria parecian quedar resguardadas al máximo, de los muchos riesgos que las amenazaban.

Desgraciadamente no fue así, Justino Fernández estaría horrorizado de ver la lamentable situación en que están hoy los murales de Orozco. ¿Cuándo se terminaron las cordiales relaciones entre el Centro de Restauración del INBAL y los encargados de las reparaciones en la Preparatoria? ¿Cuándo cesaron las inspecciones diarias a esa escuela?

El arquitecto Juan O'Gorman fue quien de nuevo lanzó el grito de alarma, su pública denuncia sobre el pésimo estado en que se encuentran los frescos de Orozco en San Ildefonso, fue a través del periódico Excelsior ( 2 de febrero de 1974), en ella considera este pintor, junto con Jorge González Camarena y José Chávez Morado, que los daños sufridos por esos frescos son irreparables. Con motivo de esas declaraciones, se ha suscitado una polémica en los principales diarios de la ciudad de México.

En los diferentes escritos que han aparecido en los periódicos se aconseja que se tomen diversas medidas de seguridad para preservar las pinturas de Orozco; todas esas disposiciones habían sido propuestas con anterioridad por Justino Fernández, quien innumerables veces suplicó a las autoridades universitarias y preparatorianas que las pusieran en práctica.

Sin embargo, frente al negro panorama que rodea a esas pinturas murales, parece que hay una esperanza de salvación, según se afirma en las optimistas declaraciones del maestro Tomás Zurián (El Día, 8 de febrero de 1974):

En contra de los pronósticos pesimistas y las declaraciones que algunas gentes han hecho al respecto, puedo opinar que, a pesar de las dificultades que 
presenta la reconstrucción de los murales, éstos serán recuperados casi en su totalidad.

Con toda seguridad, Justino Fernández, demandaría de las autoridades pertinentes, que se apresuraran a restaurar la obra mural de Orozco, no sólo los frescos de la Escuela Nacional Preparatoria, sino también los del Hospicio Cabañas en Guadalajara y otros más, cuya inminente destrucción ha sacado a relucir en estos días la prensa periódica.

Tarea interminable sería, el querer mencionar todas las opiniones que a lo largo de su vida emitió Justino Fernández, y no es ésa la finalidad del presente trabajo, en él se trata solamente de dejar constancia de esa actividad inapreciable que tan buenos frutos cosechó para nuestro legado cultural. Labor que Justino Fernández, por su natural modestia, jamás mencionó.

Sin duda alguna, muchísimo más se podría añadir a los anteriores ejemplos señalados, aquí tan sólo he apuntado algunos casós, aquellos en los que con mayor claridad se muestra el criterio, sensibilidad, inteligencia, imaginación y autoridad empleados por Justino Fernández en sus asesorías y actuaciones como salvador y reconstructor de nuestros monumentos artísticos. Lucha incansable, a la que siempre lo llevó ese sentimiento que en él tuvo una vivencia muy honda de amor y responsabilidad moral hacia el arte mexicano. 